\title{
INCIDENCE OF INDICATOR ORGANISM S, OPPORTUNISTIC AND PATHOGENIC BACTERIA IN FISH
}

$M$ hango $M *^{1}, M$ puchane $\mathrm{SF}^{2}$ and $B A$ Gashe ${ }^{3}$

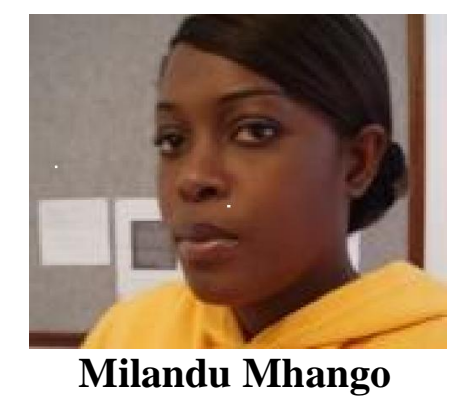

*Corresponding author email: gasheba@ mopipi.ub.bw

${ }^{1}$ Department of Basic Sciences, Daeyang Nursing College, P.O. Box 30330, Lilongwe 3, Malawi.

${ }^{2,3}$ Department of Biological Sciences, Science Faculty, University of Botswana, Pr Bag UB00704, Gaborone Botswana. 


\section{ABSTRACT}

Fish is an excellent source of high quality protein; however, it is susceptible to microbial spoilage. Fish carries high microbial load on the surface of the skin, in the intestine and in the gills. In Botswana, fishermen catch fish and sell their products in the open market. The microbiological quality and safety of these street vended fish have always been contentious. Therefore, a study on fish sold in Gaborone, Botswana was conducted from July 2006 to January 2007. Tilapia from the supermarkets and tilapia and catfish from street vendors were analyzed for the microbial load, presence of indicator microorganisms, opportunistic and pathogenic bacteria using conventional microbiological methods. Though coliforms were found in $84 \%$ of fish from the street vendors, only $16 \%$ of the fish had coliforms above the acceptable limits ( $3 \log _{10} \mathrm{CFU} / \mathrm{g}$ ). No Escherichia coli were isolated. Bacteria which are associated with plants, animals and soils but are normally classified as coliforms because of their biochemical reactions to sugars such as Citrobacter species, Klebsiella species including the enteropathogen Salmonella species were isolated. Fresh water or tap water is not available where vendors degut the fish. Hence, they carry water in containers to the point of sale sites and use it repeatedly. The unsanitary water (8.7 $\log _{10} \mathrm{CFU} / \mathrm{ml}$ of bacteria) used during the gutting of tilapia on the streets influenced the microbial levels in the fish, which were $6.0 \log _{10} \mathrm{CFU} / \mathrm{g}$ compared to the $3.90 \log _{10} \mathrm{CFU} / \mathrm{g}$ of ungutted whole tilapia from the same sale points. Frozen tilapia from supermarkets also had high bacterial counts $\left(4.8 \log _{10} \mathrm{CFu} / \mathrm{g}\right)$. Staphylococcus species were isolated frequently in all fish analyzed. Salmonella arizonae, Salmonella paratyphi (22-40\%) was only isolated in street vended fish. Other bacterial isolates from fish included Citrobacter brackii, Citrobacter freundii, Enterobacter sakazakii, Enterobacter cloacae, Vibrio cholorae, Proteus mirabilis, Proteus vulgaris, Klebsiella pneumoniae and Aeromonas hydrophila. The presence of diverse enteric bacteria indicated the degree of cross contamination from the handlers. Their presence represents a potential hazard to humans, especially the immunocompromised consumers such as cases of HIV/AIDS. Stringent regulations on registration of fishermen, traders, education and mandatory observance of sanitation at trading points and use of ice have to be enforced to ensure safety of fish consumption.

K ey words: Indicator bacteria, pathogens, tilapia, catfish 


\section{INTRODUCTION}

Fish is a perishable protein food. When fish is stored at $<10^{\circ} \mathrm{C}$, it remains for about 40 hours before it begins to spoil [1,2]. Freezing does not prevent spoilage of fish because of autolytic activities and chemical changes occurring in fish after harvest [1, 2]. The degradation of fish is accelerated by microorganisms associated with aquatic environments as well as contaminants during post-harvest handling. When fish dies, microorganisms on the surface as well as gut and gills begin to utilize the fish protein and food nutrients resulting in loss of nutritional value [3]. Microbial activities create undesirable changes like off-flavors, texture and appearance [4]. Rate of bacterial spoilage is dependent on the initial microbial load, ambient temperature and improper handling. Therefore, proper storage is critical in maintaining a high standard of safety when processing fish [2].

Small-scale fishermen either use small engine boats, dugout canoes and nets or hooks for fishing in Botswana. These fishing methods influence the microbiological and chemical quality of the fish that is brought to the markets. Hook fishing for instance keeps the earlier caught fish waiting, often ungutted and with no ice while the fisherman tries to accumulate a good number to trade [5]. In net fishing, the nets are laid overnight or for long hours. In such cases, if fish dies under water with high ambient temperatures (water temperature $18-21^{\circ} \mathrm{C}$ ) as is the case in Botswana, the spoilage begins right under water [6]. In addition to these problems faced by small scale fishermen in Botswana, there is lack of investments in landing sites processing and selling sites, resulting in poor sanitation and hygiene [7]. These problems lead to cross contamination and multiplication of microorganisms and hence poor quality of fish are presented to the consumers [7].

Studies indicate that there are several bacteria that have been isolated from three main parts of fresh fish: slime layer, gills and the gastrointestinal tract. According to Cahill [8] the microbiological diversity of the fresh fish muscle depends on the fishing grounds and environmental factors around it. Fish from warm waters mostly harbor mesophilic Gram-negative bacteria while cold waters harbour mostly psychrophilic, Gram-positive bacteria. These bacterial isolates are classified into two groups: indigenous and post- harvest bacteria.

Previous studies have also demonstrated the presence of indicator microorganisms of fecal pollution, opportunistic and pathogenic bacteria to humans in fish $[8,9,10,11$, $12]$.

The consequences of fish spoilage are far reaching, and more than just the loss of protein. There have been great economic losses reported due to foodborne illness as the result of consuming contaminated fish. The microbial association with fish compromises safety and the quality for human consumption; particularly critical is when the microorganisms are opportunistic and/or pathogenic in nature [13]. Considering the problems relating to poor handling and insufficient and improper storage facilities on the streets, the risks of contracting foodborne diseases by 
consumers may be high. These circumstances and the growing demands for fish prompted this research to look into the safety and quality of fish sold at supermarkets and by street vendors. The quality of the wash water used during degutting was also evaluated. This paper reports the microbiological quality of fish obtained from supermarkets and street vended fish caught from the Gaborone dam and Phakalane Ponds.

\section{MATERIALSAND METHODS}

Sampling was done from July 2006 to January 2007. The samples were categorized into four groups: Group 1- comprised of fifty (50) frozen tilapia from the supermarkets; Group 2- comprised of forty two (42) catfish from street vendors (none was available in supermarkets), Group 3 comprised of one hundred and one (101) gutted tilapia from the street vendors and Group 4 comprised of forty seven (47) whole ungutted tilapia from the street vendors. Thirty four whole tilapia were caught from Phakalane secondary maturation ponds by the Gaborone City Council officials for analysis.

The samples were transported within 2 hours from sampling areas to the laboratory in individual sampling bags and carried in cooler boxes filled with ice. All samples were aseptically deboned and blended at $12000 \mathrm{rpm}$ for 2 minutes and stored at $-20^{\circ} \mathrm{C}$ until analysis [9]. Frozen samples were thawed at room temperature for $10-15$ minutes and prepared as described below [14].

Total bacterial count in fish: The blended fish samples $(25 \mathrm{~g})$ were aseptically homogenized with $225 \mathrm{ml}$ of $0.1 \%$ sterile peptone water (Oxoid, CM9) in a sterile stomacher bag (Stomacher 400, Seward Medical). The 1:10 dilution in peptone water was further serially diluted. Aliquots $(1 \mathrm{ml})$ were pour-plated with sterile molten nutrient agar (Oxoid, CM3). The duplicated plates were incubated at $10^{\circ} \mathrm{C}$ for 7 days for psychrophilic/psychrotrophic and $25^{\circ} \mathrm{C}$ for 48 hours for mesophilic counts. All plates with colony forming units between 30 and 300 were recorded $[15,16,17,18]$.

Total bacterial count of wash water: Water samples $(100 \mathrm{ml})$ used during processing were collected in sterile bottles with screw-caps and transported on ice in a cooler box to the laboratory. The water samples were collected on the same day that the gutted tilapia were collected from street vendors. Serial dilutions were made with $99 \mathrm{ml}$ of sterile water up to $10^{-10}$. Aliquots of $1 \mathrm{ml}$ were poured into duplicate sterile plates and mixed with $10-15 \mathrm{ml}$ of molten nutrient agar and allowed to solidify. The plates were incubated at $35^{\circ} \mathrm{C}$ for 24 hours. All plates with colony forming units between 30 and 300 were recorded [15].

Total and Fecal coliforms: Fish samples $(25 \mathrm{~g})$ were homogenized with $225 \mathrm{ml}$ of $0.1 \%$ sterile peptone water and blended at $12000 \mathrm{rpm}$ for 2 minutes. Serial dilutions were made with $0.1 \%$ sterile peptone water. Presumptive test for total coliforms was carried out using a 3-tube multiple fermentation most probable number (MPN) technique. Aliquots ( $1 \mathrm{ml}$ of each dilution) for three consecutive dilutions were added 
to lauryl tryptose broth (LTB, Oxoid, CM451) containing test tubes. The test tubes were incubated at $35^{\circ} \mathrm{C}$ for $24-48$ hours and examined for growth and gas production. Total coliforms were confirmed by transferring a loopful of broth of positive gas production tubes into $2 \%$ brilliant green broth (BGB, Oxoid, CM31). These were incubated at $35^{\circ} \mathrm{C}$ for 48 hours $[15,16]$.

Another loopful of LTB inoculum was transferred to previously prepared EC broth for confirmatory purposes and incubated at $44.5^{\circ} \mathrm{C}$ for $48 \mathrm{~h}$ [16]. The MPN for fecal coliform was calculated on the basis of confirmed gas production using MPN tables.

Positive samples from EC broth were streaked in eosin methylene blue agar (EMBA) (Oxoid, CM69) and incubated at $35^{\circ} \mathrm{C}$ for $24-48$ hours. Escherichia coli appears as small circular colonies with green metallic sheen on eosin methylene blue agar (EMBA).These were presumed Escherichia coli and were purified on nutrient agar and subjected to morphological and biochemical tests. These were further identified by API 20E strips.

I solation and identification of Salmonella: The blended fish samples (25g) were added to 225ml of lactose broth (Oxoid, CM137) and homogenized in a stomacher for 2 minutes. The mixture was aseptically transferred into a wide-mouth screw-cap bottle and left to stand for 60 minutes at room temperature in order to enrich the population of recovering bacteria from stressful conditions. Aliquots $(1 \mathrm{ml})$ from the enrichment broth were added to $10 \mathrm{ml}$ of selenite cystine broth (Oxoid, CM699) supplemented with $4 \%$ sodium biselenite (Oxoid ECC No. 2319663). These were incubated at $35^{\circ} \mathrm{C}$ for 24 hours. After gentle mixing, a loopful of culture was streaked on to xylose lysine desocholate (XLD, Oxoid, CM469), agar and incubated at $35^{\circ} \mathrm{C}$ for $24-48$ hours. Typical Salmonella colonies which are pink with or without black centers were isolated. Some atypical Salmonella colonies which are yellow with or without black centers were also isolated. Two or more colonies from XLD were streaked and stabbed into the butt of triple iron sugar (TSI, Himedia M021) slants. These were incubated at $35^{\circ} \mathrm{C}$ for 24 hours. The test tubes that had alkaline (red) slants and acidic (yellow) butts, with or without the production of $\mathrm{H}_{2} \mathrm{~S}$ (blackening) were treated as suspects of salmonellae $[15,16]$.

From each presumptive TSI slants, a loopful was inoculated on urea broth (Himedia, M112) supplemented with $40 \%$ urea (Oxoid, SR020K). These were incubated at $35^{\circ} \mathrm{C}$ for 24 hours. All test tubes that were urease negative were treated as suspect Salmonella and confirmed by using API 20E system [15]. Further tests were conducted on pure Salmonella isolates using Salmonella Latex agglutination Wellcolex colour test (Murex Bitech Ltd, U.K.).

I solation and identification of Staphylococcus species: Staphylococcus species were isolated from fish samples $(25 \mathrm{~g})$ homogenized in $225 \mathrm{ml}$ of $0.1 \%$ sterile peptone water. Further dilutions were made as deemed necessary. Aliquots $(1 \mathrm{ml})$ were spread plated over the surface of Baird-Parker agar (Oxoid, CM275), supplemented with egg yolk emulsion (Oxoid, SR047C). The plates were incubated at $35^{\circ} \mathrm{C}$ for $24-48$ hours. 
Black, circular colonies with off-white margins were presumed to be Staphylococcus isolates.

The colonies were purified in fresh Baird-parker agar and then transferred into small tubes with $0.2 \mathrm{ml}$ brain heart infusion (BHI) broth (Oxoid CM225) and emulsified thoroughly. The emulsion was mixed with $0.5 \mathrm{ml}$ of reconstituted coagulase plasma (prolab diagnosics, PL850) with EDTA (Rochelle chemicals) was added. The mixture was incubated at $35^{\circ} \mathrm{C}$ for 6 hours, after which clot formation was observed. In addition isolates that were Gram-positive cocci, coagulase positive and negative were subjected to API Staph system (BioMeriuex, France) to identify to species level [15, $16]$.

I solation and identification of other opportunistic and pathogenic bacteria: For isolation of Vibrio, P seudomonas and other Gram-negative bacteria, the blended fish samples $(25 \mathrm{~g})$ were added to $225 \mathrm{ml}$ of alkaline peptone water (APW) with $1 \% \mathrm{NaCl}$ at $\mathrm{pH} 8.6$ for enrichment. This was incubated at $37^{\circ} \mathrm{C}$ for 8 and 24 hours. Thiosulphate citrate bile salts sucrose agar plates were streaked with a loopful of enrichment broth after 8 hours and another after 24 hours. This was done to allow for the growth of Vibrio species, which might be overtaken by the overgrowth of enteric bacteria after long hours of incubation. The plates were incubated at $37^{\circ} \mathrm{C}$ for 24 hours. Small green and yellow colonies from plates inoculated after 8 hours of incubation of enrichment broth were presumed Vibrio isolates. Typical yellow, green, blue-green and black colonies which appeared after 24 hours of incubation were purified and isolates grown on TSI agar slants and subjected salt tolerance test and Gram stain. The isolated colonies were further identified by API $20 \mathrm{E}$ system $[16,19]$.

Statistical Analysis: Statistical analysis was performed using the statistical package for social science, SPSS version 13.0 for Windows. Value of $p<0.05$ was used to indicate significant deviation.

\section{RESULTS}

Total bacterial counts: Samples of supermarket acquired frozen gutted tilapia, street vended catfish, street vended gutted tilapia, street vended whole tilapia and Phakalane ponds tilapia which had aerobic mesophilic counts $<10^{5} \mathrm{CFU} / \mathrm{g}$ were $38 \%, 27 \%, 54 \%$, $87 \%$ and $3 \%$, respectively (Table 1 ).

The average aerobic psychrophilic/psychrotrophic counts displayed only slight variation from the mesophilic counts indicating that most counts were due to psychrotrophic bacteria (Table 2). For example, $46 \%$ of the frozen samples bought from the supermarkets had psychrophilic/psychrotrophic counts of $<10^{5} \mathrm{CFU} / \mathrm{g}$. The percentage value $(46 \%)$ was higher than the mesophilic counts recorded for the same samples (38\%). The difference which was $8 \%$ must be attributed to the presence of psychrophilic bacteria while the remaining must have been psychrotrophs. 
Water samples used for degutting and scaling fish from street vendors contained aerobic mesophilic bacteria between $\log _{10} 6.46$ and $9.43 \mathrm{CFU} / \mathrm{g}$ with a mean of $8.68 \pm 1.31$ while the water used for the same purpose at the Phakalane ponds had a population of aerobic mesophilic bacteria between $\log _{10} 9.38$ and 11.2 with a mean of $10.22 \pm 0.874 \mathrm{CFU} / \mathrm{g}$.

Prevalence of Total coliforms (TC), Fecal coliforms (FC) and E scherichia coli: In spite of the high prevalence rates of total coliforms in the fish samples studied, several of the samples had counts in the range of 0.9 to $4.88 \mathrm{CFU} / \mathrm{g}$ (Table 3). The frozen tilapia from the supermarkets had the highest (84\%) prevalence rate for total coliforms with samples having $\log _{10} 0.9$ to $4.04 \mathrm{CFU} / \mathrm{g}$ (Table 3); however, most of the samples $(>50 \%)$ had total coliform counts $<\log 102.5 \mathrm{CFU} / \mathrm{g}$ (Fig. 1). Fifty percent of the supermarket acquired fish samples had total coliforms above the acceptable limits of bacterial counts of raw foods (Table 4).

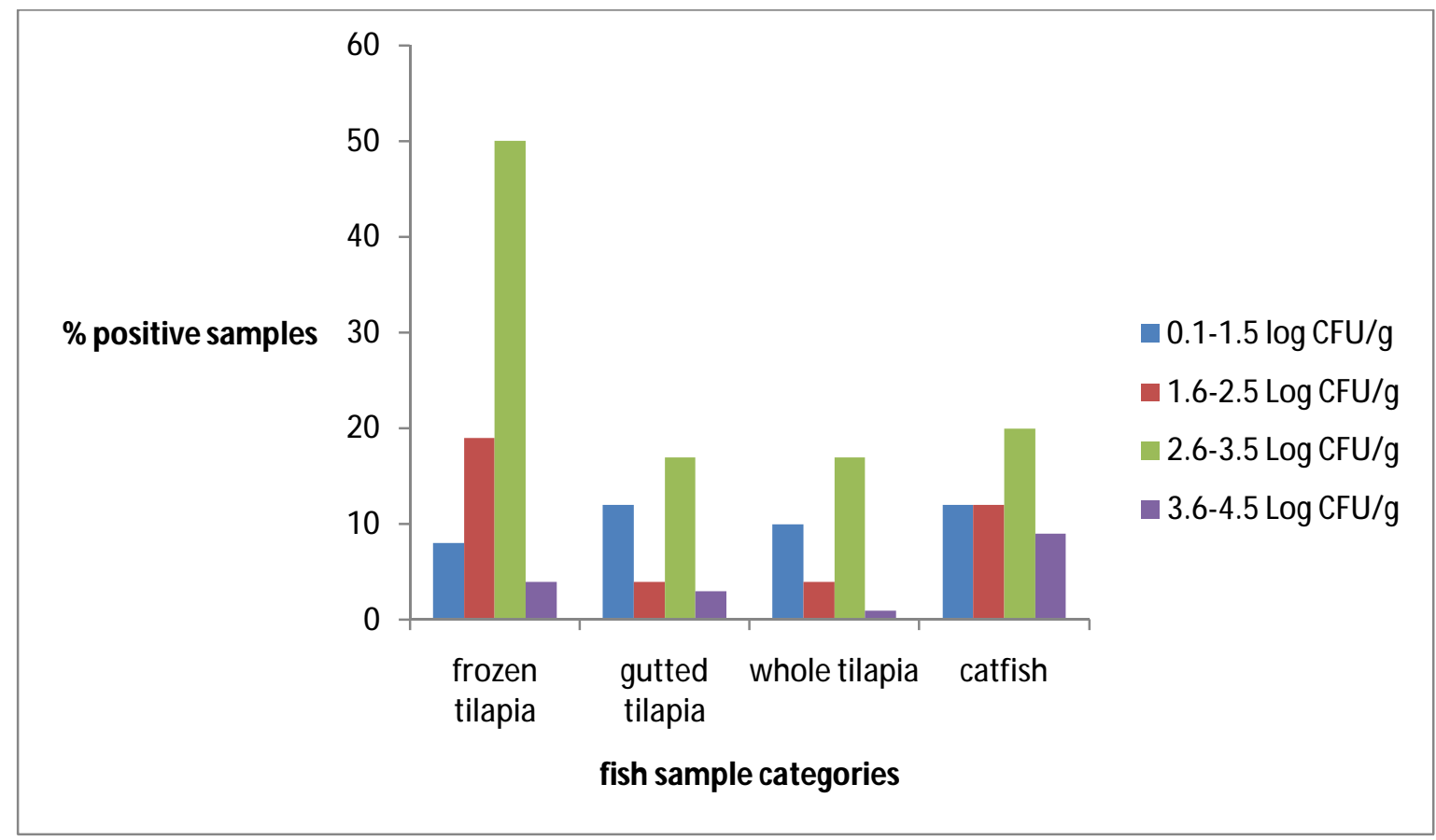

Figure 1: Total coliform loads in fish marketed in Gaborone

Gutted tilapia samples from street vendors had total coliforms of $47 \%$ and fecal coliforms of $34 \%$ (Table 3 ).

Whole tilapia had the lowest (36\%) prevalence rate for total coliforms (Table 3). In the whole tilapia samples the total coliform count was in the range of 0.95 to 3.38 $\log _{10} \mathrm{CFU} / \mathrm{g}$ whilst the fecal coliform counts reached only to a high of $1.63 \log _{10}$ $\mathrm{CFU} / \mathrm{g}$. Few of the samples had total coliform counts above $2.5 \log _{10} \mathrm{CFU} / \mathrm{g}$ (Figure 1 ); only two samples $\left(4 \%\right.$ ) had fecal coliforms at $0.1-1.5 \log _{10}$ CFU/g (Figure 2). Only one sample of the whole tilapia had coliform counts above the acceptable limits 
in food (Table 4). No Escherichia coli were isolated from all the fish samples in this study.

Occurrence of pathogens: Food-borne opportunistic bacteria, emerging pathogens and pathogenic bacteria like Citrobacter bracki, Staphylococcus xylosus, Staphylococcus scuiri, Salmonella arizonae, Enterobacter sakazakii and Enterobacter cloacae were isolated from various fish samples (Table 5).

No Salmonella was isolated from the frozen supermarket fish. Whole tilapia from the street vendors had the highest (40\%) Salmonella occurrence. This was followed by catfish $(30.9 \%)$ and gutted tilapia $(21.8 \%)$ from the streets (Table 5). The most common serogroups of Salmonella isolated in catfish, whole tilapia and gutted tilapia were in decreasing order: serogoups $\mathrm{A}>\mathrm{E} / \mathrm{G}>\mathrm{C}>$ and lastly Vi (Table 6).

Staphylococcus species were isolated in $53 \%$ of the fish samples (Table 5). The highest prevalence was in frozen tilapia from the supermarkets and whole tilapia from the street vendors (86\% and 62\%, respectively). All the Staphylococcus isolates were coagulase negative and were identified as Staphylococcus xylosus and Staphylococcus scuiri and Micrococcus.

Gutted tilapia had the highest (10 isolates) diversity of potential pathogens. Some of the isolates were Klebsiella pneumoniae, Proteus vulgaris, Proteus mirabilis, Aeromonas hydrophila and Vibrio cholerae. This was followed by whole ungutted tilapia with (5 isolates), frozen tilapia (4 isolates) and catfish (3 isolates).

Enterobacter species were isolated from gutted tilapia samples only (Table 5).

\section{DISCUSSION}

Total bacterial counts: A high population of bacteria in food indicates the general quality of the food and the degree of spoilage it might have undergone. The occurrence of total bacterial counts of many of the samples investigated having $>10^{5}$ $\mathrm{CFU} / \mathrm{g}$ raises concern about the hygienic status of the production and point of sale environment.

Of concern was the occurrence of psychrophilic/psychrotrophic bacteria above acceptable limits. The specification for bacterial counts of fish which is $<10^{5} \mathrm{CFU} / \mathrm{g}$ is considered acceptable [15]. The high bacterial counts in the supermarket acquired gutted tilapia and processed catfish suggested poor handling during the gutting and scaling process by vendors. The high bacterial counts especially in the catfish supports the argument that the water in use during degutting becomes highly contaminated with psychrophilic/psychrotrophic bacteria.

Psychrophiles though present in fewer number in the samples could bring about significant spoilage of the fish. This is because they are at their optimum temperature range $\left(\mathrm{ca} 10^{\circ} \mathrm{C}\right.$ ) and grow faster than the psychrotrophs. The psychrotrophs, which are 
truly mesophiles, grow at a much slower rate at $10^{\circ} \mathrm{C}$. The same reasoning could be applied where the psychropilic counts of samples are compared with the mesophilic counts for the other samples.

Studies conducted by Gashti et al. [20] found psychrophiles isolated from minced freshwater fish even when incubated at $0^{\circ} \mathrm{C}$. The high psycrophilic/psychrotrophic count in the supermarket tilapia samples examined in the current study may have been caused by temperature fluctuations of the refrigerated vans or storage freezers in the shops thereby allowing for the multiplication of the initial bacteria that have lodged on the skin of tilapia in supermarkets from processing stages.

The low bacterial counts of whole tilapia compared to the gutted tilapia from street vendors, suggest to what extent reusing water can contribute to the microbial load of the street vended fish. According to Reij et al. [21] poor hygiene and unsanitary handling of food are the causes of contamination of food. This study has demonstrated that there were possibilities of cross contamination that resulted from the improper handling of tilapia during the processing on the streets.

Most of the catfish samples had mesophilic and psychrotrophic bacteria above the acceptable limits of bacterial counts $\left(10^{5} \mathrm{CFU} / \mathrm{g}\right)$ for food. The high mesophilic counts could have been from the evisceration of the catfish on the streets. The cross contamination of viscera and flesh could have occurred. Leung et al. [22], found that catfish had a high viscera bacterial count and this was reflected in the microbial counts in the catfish flesh. This could also be the case in this study where catfish were improperly handled. The slow air drying of the catfish in unsanitary environments attracted flies and insects which might also have contributed to the higher bacterial counts.

Prevalence of Total coliforms (TC), Fecal coliforms (FC) and Escherichia coli: The incidence of coliforms on fifty percent of supermarket acquired fish led to the conclusion that this contamination took place during the degutting process of the tilapia and contamination from the surrounding environment and before freezing. This finding is in agreement with the findings of Aranilewa et al. [23] where an increasing coliform count with a prolonged frozen storage of fish was observed. They argued that possible temperature fluctuations of the freezers, time taken during the processing, time taken to transport and trade the fish might have contributed to the high coliform counts.

While no E.coli was isolated from all the fish investigated, the very presence of coliforms above the acceptable limit in fish, marketed on the streets presents a risk to the consumers. This is because coliforms grow rapidly at ambient temperatures and spoil the fish in a short period of time [24]. Most of all, biogenic amines such as putrescine, tyramine and histamine might also be produced. These chemicals are responsible for various ailments in humans [10]. 
Occurrence of pathogens: The occurrence of Salmonella on street vended whole tilapia, gutted catfish and tilapia and not from frozen supermarket fish suggests a temperature effect. Wyatt et al. [25] found high prevalence of Salmonella in catfish and the high rates were attributed to the high temperatures in pond water, which promoted the growth of Salmonella species as well as the cross contamination from viscera to flesh during processing. Similar situations existed here where ambient temperature could be $25-35^{\circ} \mathrm{C}$ during day time might have contributed to the growth of salmonellae in the flesh. But unhygienic processing conditions and absence of clean water during degutting might have contributed to the contamination followed by growth of the bacteria. Provision of low temperature storage is therefore indicated.

The high prevalence of Staphylococcus in the fish samples indicated the unhygienic handling of the fish since these species are found on human skin. Gonzalez-Rodriguez et al. [26] found members of the Micrococcae family to be the third most abundant group of bacteria isolated from fresh water fish they studied. In addition to these, Gelman et al. [27] also isolated Micrococcus species in $80 \%$ of the fish samples studied. The tilapia had more Staphylococcus than the catfish in this study though the handling and processing were very similar.

The diversity of potential pathogens from the samples of fish is of concern particularly at a time when many in our communities are immunologically compromised as a result of various illnesses. These opportunistic and pathogenic bacteria were also previously isolated by several other researchers from fish [28, 29, $30,31,32]$.

The occurrence of Enterobacter species in gutted tilapia samples only was similar to results of Paleologos et al. [32] who found bacteria belonging to the Enterobacteriaceae family as predominant in whole gutted and filleted sea bass. Elmossalami et al. [33] found Enterobacteriacea ( $3.5 \times 10^{5} \mathrm{CFU} / \mathrm{g}$ ) in crayfish from the Nile River. Gonzalez-Rodriguez et al. [34] and Tsai et al. [30] also found that bacteria belonging to Enterobacteriaceae family were the predominant isolates in the fish samples. This is expected since enterobacteria are not only found in the gut but also quite a few species are also found in the environment. Species such as Klebsiella pneumoniae and Enterobacter sakazaki are known to be found in the environment inhabiting plants. The emerging pathogen, Enterobacter sakazaki, causes a lot of food borne outbreaks in children, elderly and immuno-compromised patients. The presence of these opportunistic and pathogenic members of bacteria in fish represents a threat to vulnerable groups in society.

\section{CONCLUSION}

This study has revealed a moderate level of bacterial contamination of fish sold in supermarkets and by street vendors. The lack of knowledge of sanitary handling of food and poor processing conditions on the streets contributed to the high bacteria levels in the fish. The gutting of fish by street vendors in the absence of freely flowing water introduced more pathogens to the fish. The lack of infrastructure and use of ice 
at street sale point may have allowed for the growth of bacteria on the fish. The cold chain and sanitary processing of the super marketed fish may not have been exclusively followed and hence the bacterial high levels in the frozen fish. These circumstances, therefore, represent a potential health risk to fish eating society in the country if left unmonitored.

The high incidence of Salmonella in the fish from street vendors is a major health concern. In addition to salmonellae, the presence of diverse enteric bacteria in fish indicates the contamination from handlers, representing a potential hazard to human health especially those who are sick or are on immunosuppressive drugs. Stringent regulations and monitoring activities coupled with food safety training of suppliers (fishermen and traders) and consumers on various aspects of Good Hygiene Practice (GHP), Good Manufacturing Practice (GMP) and HACCP is strongly recommended.

\section{ACKNOWLEDGEMENTS}

I (Milandu Mhango, MSc Applied Microbiology student) would like to thank the World Bank, through the Malawi Government - Education Sector Support Project (ESSUP 1), for offering me a scholarship to pursue this study. The help rendered by the staff in the Department of Biological Sciences, University of Botswana is highly appreciated. 
Table 1: M icrobial population distribution in fish incubated at mesophilic range of temperature

$\%$ of samples in population ranges , $\log _{10} \mathrm{CFU} / \mathrm{g}$

\begin{tabular}{|c|c|c|c|c|c|}
\hline Sample & $10^{2}-10^{3}$ & $10^{3}-10^{4}$ & $10^{4}-10^{5}$ & $10^{5}-10^{6}$ & $>10^{6}$ \\
\hline \multicolumn{6}{|l|}{ Supermarket fish } \\
\hline $\begin{array}{l}\text { Frozen gutted } \\
\text { tilapia }\end{array}$ & 8 & 10 & 20 & 48 & 14 \\
\hline \multicolumn{6}{|l|}{ Street vended fish } \\
\hline Catfish & 0 & 17 & 10 & 17 & 58 \\
\hline Gutted tilapia & 0 & 17 & 38 & 29 & 17 \\
\hline Whole tilapia & 17 & 43 & 28 & 13 & 0 \\
\hline \multicolumn{6}{|l|}{ Phakalene fish } \\
\hline Whole tilapia & 0 & 0 & 3 & 3 & 94 \\
\hline
\end{tabular}

Table 2: M icrobial population distribution in fish incubated at psychrophilic range of temperature

$\%$ of samples in population ranges, $\log 10 \mathrm{CFU} / \mathrm{g}$

Sample

$10^{2}-10^{3}$

$10^{3}-10^{4}$

$10^{4}-10^{5}$

$10^{5}-10^{6}$

$>10^{6}$

Supermarket fish

Frozen gutted tilapia 16

4

26

40

14

Street vended fish

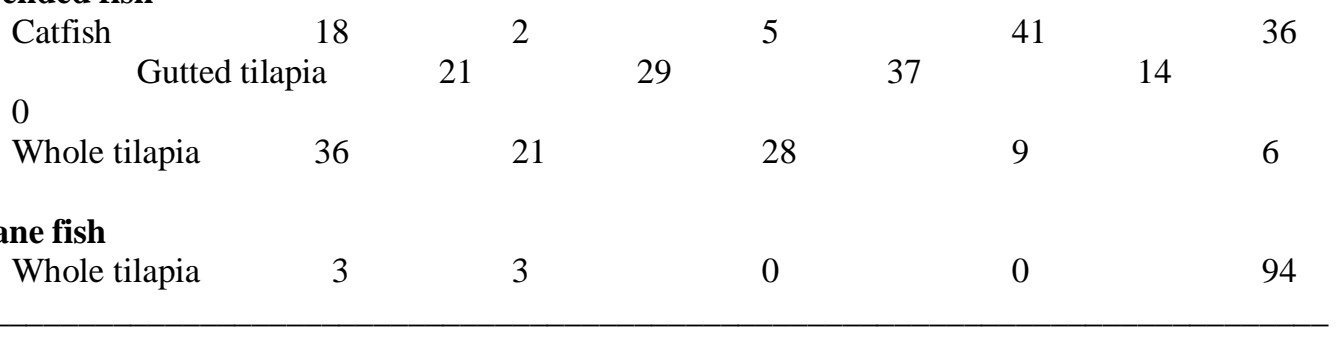




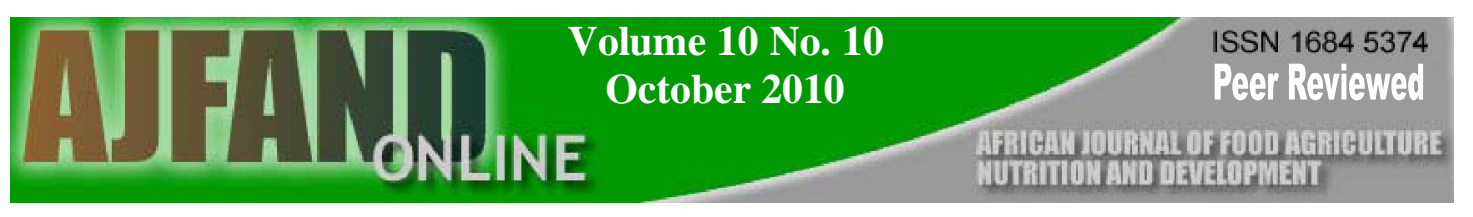

Table 3:The percentage of samples with coliforms and range of population ( $\log _{10}$ CFU/g)

\begin{tabular}{|c|c|c|c|c|}
\hline & \multicolumn{2}{|c|}{ TOTAL COLIFORMS } & \multicolumn{2}{c|}{ FECAL COLIFORMS } \\
\cline { 2 - 5 } Sample category & $\begin{array}{c}\text { \% positive } \\
\text { samples }\end{array}$ & $\left(\log _{10}\right.$ CFU/g) & $\begin{array}{c}\text { \% positive } \\
\text { samples }\end{array}$ & $\left(\log _{10}\right.$ CFU/g) \\
\hline $\begin{array}{c}\text { Supermarket fish: } \\
\text { Frozen Tilapia }\end{array}$ & 84 & $0.9-4.04$ & 80 & $0.6-4.04$ \\
$\begin{array}{c}\text { Street vended fish: } \\
\text { Gutted Tilapia }\end{array}$ & 47 & $0.95-4.88$ & 34 & $0.6-3.38$ \\
$\begin{array}{c}\text { Whole Tilapia } \\
\text { Catfish }\end{array}$ & 36 & $0.95-3.38$ & 5 & $0.6-1.63$ \\
Phakalane Fish & 53 & $0.9-3.63$ & 41 & $1.36-3.63$ \\
Whole Tilapia & 65 & $1.95-3.38$ & 59 & $1.95-3.39$ \\
\hline
\end{tabular}

Table 4: Number (\% ) of samples with total coliform and fecal coliform beyond acceptable limits*

\begin{tabular}{|l|c|c|}
\hline Fish category & $\begin{array}{l}\text { Prevalence of total } \\
\text { coliform }\end{array}$ & $\begin{array}{l}\text { Prevalence of fecal } \\
\text { coliform }\end{array}$ \\
\hline $\begin{array}{l}\text { Supermarket fish: } \\
\text { Frozen tilapia }\end{array}$ & $25(50 \%)$ & $16(32 \%)$ \\
Street vended fish: & $4(4 \%)$ & $2(2 \%)$ \\
Gutted tilapia & $1(2.1 \%)$ & $0(0 \%)$ \\
Whole tilapia & $7(16.6 \%)$ & $7(16.6 \%)$ \\
Catfish & & $4(11.8 \%)$ \\
Phakalane fish & $8(23.5 \%)$ & \\
Whole tilapia & & \\
\hline
\end{tabular}




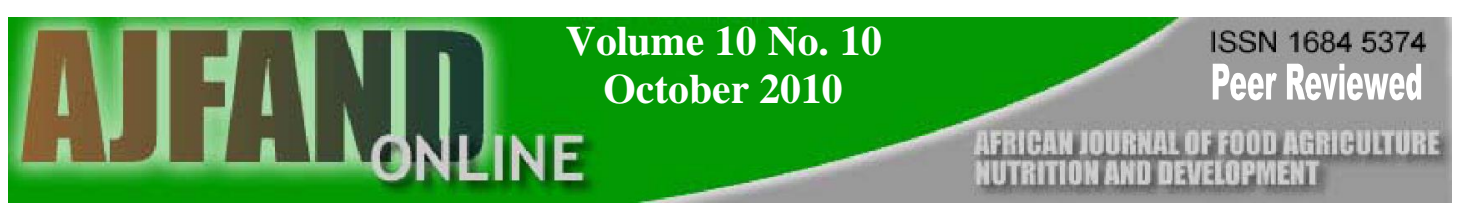

Table 5: The prevalence of pathogens in fish sold in Gaborone, Botswana (\%)

\begin{tabular}{|l|l|l|l|l|}
\hline Isolates & Catfish & $\begin{array}{l}\text { Frozen } \\
\text { tilapia }\end{array}$ & Whole tilapia & $\begin{array}{l}\text { Gutted } \\
\text { tilapia }\end{array}$ \\
\hline Aeromonas hydrophila & $-{ }^{\mathrm{a}}$ & - & - & $8 \%$ \\
Citrobacter braakii & $33 \%$ & $54 \%$ & $31 \%$ & $49 \%$ \\
Citrobacter freundii & - & $29 \%$ & $2 \%$ & - \\
Enterobacter sakazakii & - & $13 \%$ & $40 \%$ & $6 \%$ \\
Enterobacter cloacae & - & - & - & $4 \%$ \\
Klebsiella pneuminiae & - & - & - & $2 \%$ \\
Proteus vulgaris & - & - & - & $4 \%$ \\
Proteus mirabilis & - & - & - & $1 \%$ \\
Salmonella species & $31 \%$ & - & $40 \%$ & $22 \%$ \\
Staphylococcus species & $36 \%$ & $86 \%$ & $62 \%$ & $41 \%$ \\
Vibrio cholera & - & - & - & $1 \%$ \\
\hline
\end{tabular}

- $^{\mathrm{a}}$ signifies absence of the bacteria.

Table 6: Percentage (\% ) occur rence of Salmonella serogroups in fish from markets in Gaborone, Botswana

\begin{tabular}{|l|l|l|l|}
\hline Serogroups & catfish & Whole tilapia & Gutted tilapia \\
\hline $\mathrm{A}$ & $7(16.6 \%)$ & $13(27.7 \%)$ & $10(9.9 \%)$ \\
$\mathrm{E} / \mathrm{G}$ & $4(9.5 \%)$ & $6(12.8 \%)$ & $9(8.9 \%)$ \\
$\mathrm{C}$ & $2(4.8 \%)$ & $0(0 \%)$ & $1(1 \%)$ \\
$\mathrm{Vi}$ & $0(0 \%)$ & $0(0 \%)$ & $2(2 \%)$ \\
\hline
\end{tabular}




\section{REFERENCES}

1. Huss HH, Pedersen A and DC Cann The incidence of Clostridium botulinum in Danish trout farms. I Distribution in fish and their environment. II Measures to reduce contamination of the fish, J ournal of F ood Technology 1974; 9: 445 458.

2. J ay J M Modern Food Microbiology $4^{\text {th }}$ edition. Chapman \& Hall; London, 1992; 199-233.

3. Ames GR The Kinds and Levels of Post-harvest Losses in African inland Fisheries. Food Agriculture Organization of the United Nations. Rome Italy, 1992; CIFA Technical Paper 19.

4. Johnstone WA, Nicholson FJ, Roger A and GD Stroud Freezing and Refrigerate Storage in Fisheries. 1994; FAO Fisheries Technical Paper No. 334 Rome. FAO 143pp.

5. Purvis J Post harvest fisheries on the eastern flood plains, Caprivi 2002; DEA Research Discussion Paper 51 29pp.

6. Regenstein J M Processing and marketing aqua cultured fish: 1992; NRAC Fact sheet No. 140. University of Massachusetts, Dartmouth.

7. M mopelwa TC Sun-Dried Salted Fish as a Means of Reducing Post Harvest Losses in Botswana. Proceedings of the Symposium on Post-Harvest Fish Technology (21-22 October 1990). 1992; CIFA Technical paper No.19 pages 117.

8. Cahill M M Bacterial flora of fishes: a review, Journal of Microbial Ecology 1990; 19 (1): 21- 41.

9. Da Silva M V, Pinho O, Ferreira I, Plestilova L and PA Gibbs Production of Histamine by Bacteria Isolated from Portuguese Vacuum Packed Cold Smoked Fish, J ournal of F ood Control 2002; 13:457-461.

10. Tsai yung-Hsiang, Chang Shiou-chung, K ung Hsien-fung, wei Chung and Hwang dung-fwu Histamine Production by E. aeregenes in Salifish and Milkfish at Various Storage Temperatures, J ournal of Food Protection 2002; 68 (8); 1690-1695.

11. Ferreira IM and $O$ Pinho Biogenic amines in Portuguese traditional foods and wines, J ournal of F ood P rotection 2006; 69 (11): 2293 - 2303.

12. Tzikas Z, Amvrosiadis I, Soultos N and SP Georgakis Seasonal size distribution, condition status and muscle yield of of Mediterranean Horse Mackerel (Trachurus mediterraneus) from the North Aegean Sea Greece, J ournal of F isheries Science 2007; 73 (2): 453 -462. 
13. World Health Organization Essential safety requirements for street-vended foods. Food safety Unit .1996; Division of food and Nutrition. WHO.

14. C unnif P Official Methods of Analysis of AOAC International Volume II. Food Composition; Additives; Natural contaminants. 1999; AOAC International, Maryland.USA.

15. A ndrew W Manual of Food Quality Control 4. Rev.1. Microbiological analysis. FAO of the United Nations. Rome. 1992; FAO food and nutrition paper.14/4 Rev.1.

16. FDA. Bacteriological Analytical Manual. $7^{\text {th }}$ Edition. 1992; AOAC international 2200 Wilson Blvd, Suite 400, Arlington, VA.

17. Trytinopoulou P, Tsaka-lidou E and GJE Nychas Characterization of Psuedomonas Spp Associated with Spoilage of Gilt-Head Sea Bream Stored under Various Conditions, Applied and Environmental M icrobiology 2002; 68 (1):65-72.

18. Baixas-Nogueras $\mathrm{S}, \mathrm{B}$ over-Cid $\mathrm{S}, \mathrm{V}$ eciana-Nogues $\mathrm{MT}, \mathrm{M}$ arine-F ont $\mathrm{A}$ and MC Vidal-Carou Biogenic Amine Index for Freshness Evaluation in Iced Mediterranean Hake (M erluccius merluccius), J ournal of F ood Protection 2005; 68 (11): 2433-24 38 .

19. Corry J EL, Roberts D and FA Skinner (1982). Isolation and Identification Methods for Food Poisoning Organisms. Academic Press. London, 1982.

20. Gashti GZ Estimation of microbiological and chemical variation in minced fish processing of Atlantic Pollock (Pollachiu vireos. Iranian Fisheries Research Organization. Sturgeon International Research Institute, 2002.

21. Reij MW and ED Den Aantrekker Recontamination as a source of pathogens in processed foods International Journal of Food M icrobiology 2004; 91 : 111.

22. Leung $\mathrm{C}-\mathrm{K}$, Huang $\mathrm{YW}$ and $\mathrm{OC}$ Pancorbo Bacteria pathogens and indicators in catfish and pond environments, J ournal of Food Protection 1992; 55: 424427.

23. Arannilewa ST, Salawu SO, Sorungbe AA and BB Ola-Salawu Effect of frozen period on the chemical microbiological and sensory quality of frozen tilapia fish (Sarotherodun galiaenus), African J ournal of Biotechnology 2005; 4 (8): $825-855$.

24. Geldreich EE and NA Clarke Bacterial pollution indicators in the intestinal tract of freshwater fish, Applied Environmental Microbiology 1966; 14 (3): 429 -437 . 
25. Wyatt LE, Nickelson $R$ and $C$ Vanderzant Occurrence of and control of Salmonella in freshwater catfish. J ournal of Food Science 1976; 44 (4): $1067-$ 1073.

26. Gonzalez-Rodriguez C, Lopez-Diaz T, Gracia-Lopez M, Prieto M and A Otero Bacterial microflora of wild trout (Salmo trutta), wile pike (E sox lucius) and aquacultured rainbow trout (Oncorhynchus mykiss), Journal of Food Protection 1999; 62 (11): 1270 - 1277.

27. Gelman A, Glatman L, Drabkin V and S Harpaz Effect of storage temperature and preservative treatment on shelf life of pound-raised freshwater fish, silver perch (Bidyanus bidyanus), J ournal of F ood Protection 2001; 64, pp. 1584-1591.

28. Ogbondeminu FS The occurrence and distribution of enteric bacteria in fish and water of tropical aquaculture ponds in Nigeria, J ournal of Acquaculture in the Tropics 1993; 8 (1): $61-66$.

29. M ungati D, M watha WE and P Okeno Salmonella and Vibrio Cholerae in Nile perch (Lates niloticus) processing establishments in Kenya, Journal of Tropical M icrobiology 2002; 1: $79-88$.

30. Tsai $Y H, K$ ung HF, Lee TM, Lin GT and DF Hwang Histamine related hygienic qualities and bacteria found in popular commercial scombroid fish fillets in Taiwan, J ournal of F ood Protection 2004; 67 : 407-412.

31. Y imer E Bacteria, Edwardsiella tarda, fish disease, Lake Ziway parasites, Ethopian J ournal of Science 2000; 23 (1): 25 -33.

32. Paleologos EK, Savvaidis IN and MG Komtominas Biogenic amine formation and its relation to microbiological sensory attributes in ice-stored whole gutted and filleted Mediterranean Sea bass (Dicentrarchus labrax). International J ournal of F ood M icrobiology 2004; 21 (5): 549 - 557.

33. Elmossalami MK Safety and quality of freshwater crayfish Procambarus clarkii in the Nile River. J ournal of Tropical Microbiology 1997; 43: $126-128$.

34. Gonzalez-Rodriguez MN, Sanz JJ, Santos JA, Otero A and MI GarciaLopez Numbers and types of microorganisms in vacuum-packed cold-smoked freshwater fish at the retail level, International J ournal of Food Microbiology 2002; 77 (1-2): 161- 8. 